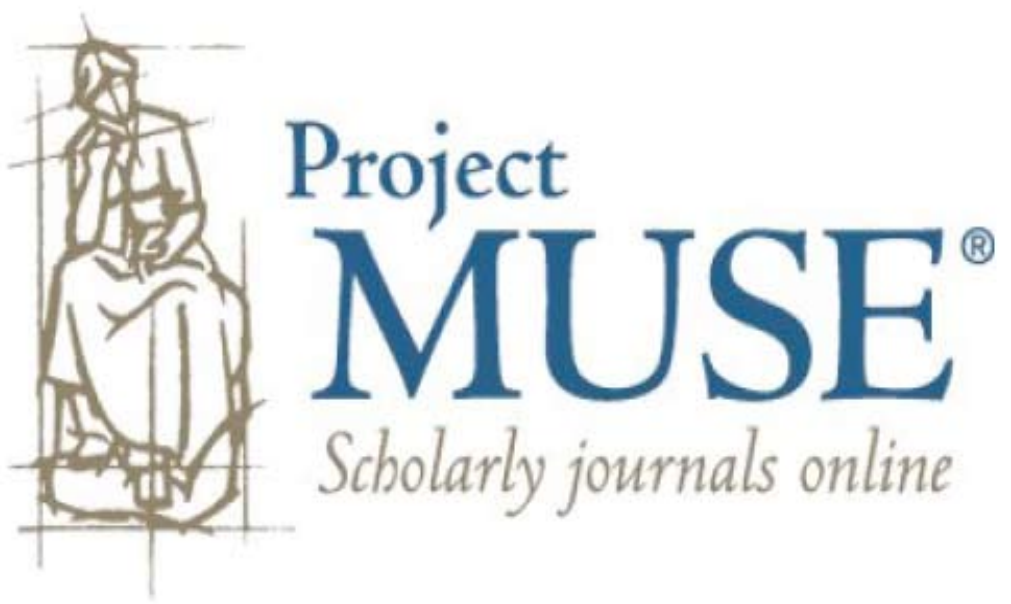




\title{
The Culture of Honor: How Slaveholders Responded to the Abolttionist Mail Crisis OF 1835
}

\author{
JeNNIFER ROSE MERCIECA
}

In the summer of 1835 northern abolitionists mailed over 100,000 anti-slavery newspapers to slaveholders in the South, which led slaveholders to violently prevent the abolitionist sentiment from circulating in their local communities. In analyzing the discourse produced by the crisis, I argue that the slaveholders' expert use of the norms of community obligation, which were supported by the rhetoric of honor, allowed them both to reassert control over the national abolition debate and to retain their local status and privilege.

The post office department was created to serve the people of each and all of the United States, and not to be used as the instrument of their destruction. None of the papers detained have been forwarded to me, and I cannot judge for myself of their character and tendency; but you inform me, that they are, in character, "the most inflammatory and incendiary—and insurrectionary in the highest degree." By no act, or direction of mine, official or private, could I be induced to aid, knowingly, in giving circulation to papers of this description, directly or indirectly. We owe an obligation to the laws, but a higher one to the communities in which we live, and if the former be perverted to destroy the latter, it is patriotism to disregard them. ${ }^{1}$

$\mathbf{P}$ ostmaster General Amos Kendall was sufficiently outraged by "inflammatory and incendiary" newspapers that he could recommend to his

Jennifer Rose Mercieca is Assistant Professor of Communication at Texas A\&M University in College Station. She wishes to thank Jim Aune, Stephen Browne, Ted George and Anthony Mora, who each suggested how this essay could be improved. Her grateful thanks are also due to Marty Medhurst and the anonymous reviewers of R\&PA who generously offered their wise counsel and support.

(C) Rhetoric \& Public Affairs

Vol. 10, No. 1, 2007, pp. 51-76

ISSN 1094-8392 
subordinate-Charleston, South Carolina's Postmaster Alfred Huger-that he suppress these papers as an act of local "patriotism." Kendall's letter of August 4, 1835, was written in response to supplications from Huger for advice about "incendiary missiles"-abolitionist newspapers-mailed by "miserable fanatics" to "inflame the whole country."2 And inflame the whole country The Emancipator, The Slave's Friend, Human Rights, and the AntiSlavery Record did. Within a matter of days angry citizens seized and destroyed the mail in Charleston, South Carolina, while postmasters and ship captains censored further mail from "bombing" the South. Within weeks the still enraged citizens of Georgia, Mississippi, Virginia, and South Carolina had passed laws and resolutions outlawing the newspapers and had formed themselves into Committees of Safety, ostensibly to enforce the peace. Enforcing the peace meant closing black schools, burning northern abolitionists in effigy, and imprisoning and often lynching anyone suspected of accepting the newspapers, and thus, harboring the outlawed "fanatical" and "insurrectionary" opinions. Not all of their strategies, though, involved such sensational and violent public displays; slaveholders also employed more subtle means of establishing their authority over the abolition debate. As William W. Freehling notes in his seminal The Road to Disunion, "neighbors' ostracism would deter those wishing incendiary mail." ${ }^{3}$ Ostracism was a viable strategy for reasserting control precisely because, as Kendall's letter attests, southerners believed that they owed a "higher obligation," - or their loyalty-to their local communities and thus would not hazard shameful disapproval. In short, the pressure of local obligation could be relied upon to define, enforce, and punish unacceptable opinions and behavior.

The controversy over the abolitionists' mail simultaneously raised questions about the freedom of the press, the purpose of the post office, and the ability of southerners to control their public sphere. In other words, communication and communication technologies were at the center of the debate over abolition in 1835. Yet, despite the apparent significance of the abolitionist mail crisis to scholars of rhetoric and public affairs, the story has been obscured behind the larger stories of the decade: the Nullification Crisis, the Nat Turner Slave Rebellion, and the Gag Rule Controversy. This is a regrettable lacuna because a sustained analysis of the crisis will not only add to our understanding of the rhetorical moves made by antebellum slaveholders in their quest to maintain power and slavery, but will also add to our understanding of the ways in which the mandates of obligation and honor worked together to define the limits of acceptable southern behavior and southern rhetoric. Specifically, I argue that slaveholders successfully relied upon the rhetorical techniques inherent in the "culture of honor"-unification, vigilance, and threats-to control the public discourse about abolition in 1835 . 
To understand this complex discourse I first review the relevant rhetorical and historical scholarship on antebellum slaveholder rhetoric. Next, I retell the story of the crisis, paying particular attention to how slaveholders used the norms of community obligation to control the southern public sphere. Finally, I delineate the main features of the "rhetoric of honor." Specifically, I describe how the mandates of community obligation and the fear of community shame led to discourse designed to defend community norms, silence enemies, and restore reputations. I conclude that the rhetoric of honor is not limited to slaveholders' defenses of slavery, but reflects tensions inherent in American political rhetoric.

\section{Scholarship on Antebellum Rhetoric and Abolition}

There has been a surprising paucity of interest in rhetorical scholarship about why and how slaveholders justified their belief that slavery was just, expedient, or necessary. Yet, it is important to understand this discourse because slaveholders exercised extensive power in antebellum America. ${ }^{4}$ It is easy for us today to sympathize with the abolitionist perspective, but it takes a concerted effort to look at the world through the perspective of the slaveholder-no one wants to be accused of making a hero out of antebellum slaveholders. It is not surprising, therefore, that in the field of rhetorical studies one would have to go back to 1987 and the work of Donald K. Enholm, David Curtis Skaggs, and W. Jeffrey Welsh to find an essay that probes the difficult terrain of the development of the "southern mind." Yet, even that essay only concerns itself with the southern mind prior to 1770 . Even the best recent attempts by rhetorical scholars to understand the peculiar ways of southerners does not approach the question of slavery from the slaveholders' perspective. ${ }^{5} \mathrm{~V}$. William Balthrop examined the relationships of culture, myth, and ideology in the creation, defense, and demise of southern culture, but seemingly did not consider slaveholder rhetoric as a fundamental piece of that culture. The unfashionable topic of the defense of slavery has thus suffered from a lack of recent attention. The examination of the mail crisis grants scholars of rhetoric and public affairs a unique opportunity to view how southerners developed and deployed a new rhetoric on slavery at a moment of crisis.

Historians have long understood the abolitionist mail crisis of 1835 as an intermediate step in the growing hostilities between slaveholders and abolitionists in antebellum America. They place it into the context of several key events from 1819 to 1835: the debate over the Missouri Question in 1819-20; Denmark Vesey's potentially deadly insurrection in South Carolina in 1822; New York's final elimination of slavery in 1827; David Walker's publishing of the Appeal in 1829; William Lloyd Garrison's publishing of the Liberator in 
1831; Nat Turner leading 60 fellow sufferers on a 48-hour rampage in Southampton County, Virginia, and the Virginia legislature publicly debating abolition, but deciding that the time was not yet ripe to take action in 1832; the American Anti-Slavery Society (AASS) vowing to fight for immediate abolition, agitating for the abolition of the slave trade in Washington, D.C., and publishing its four newspapers devoted to immediatism in 1833; and, in the summer of 1835, Mississippi's Madison and Hinds counties erupting in a panic over rumors of a white-led slave revolt, which was followed closely by abolitionist newspapers appearing in southern mail bags.

While it is clear that sectional hostilities were beginning to grow in the 1830 s, it is important to note that the question of abolition was not an easy binary between southerners and northerners. Yet, as the above chronicle attests, it is also clear that by 1835 there were those who were willing to agitate for abolition and those who were willing to use violence to defend slavery. Therefore, we would do well to think of the abolitionist mail crisis of 1835 as a part of - indeed, it could be considered an escalation of - the rhetorical war between slaveholders and abolitionists in Antebellum America. As William Freehling noted, slaveholders in the 1830s lived amongst their "family friends" with an increasing fear of insurrection. This fear prompted many slaveholders to view abolitionists' newspapers' intrusion into their public sphere as an overt act of aggression. ${ }^{6}$ Indeed, while still at the margins of power and popular public opinion in 1835 , abolitionism was becoming more vocal and more strident in its demands, which led to the innovation of new, more confrontational, tactics like the "mail bombing" of the South.

I build from the work of several historians who have studied the controversy: Bertram Wyatt-Brown argued that by 1835 abolitionism had "reached a crisis" and thus, that it was "essential for the Anti-Slavery Society to reorganize its publications, to raise more funds, and to resolve internal bickerings in common effort." By 1835, writes Wyatt-Brown, "the time had come to make the country aware of abolitionism."7 To achieve this goal the AASS "decided to flood the country with antislavery literature" by drawing up a mailing list of "over twenty thousand Southerners" and sending over "one hundred and seventy-five thousand copies" of their four periodicals to the South through the New York Post Office. ${ }^{8}$ Thus, the AASS consciously devised their new southern strategy with the goal of drawing attention to the cause of abolition, but not necessarily in the hope of persuading southern slaveholders of the evils of slavery. This is noteworthy, because as will become apparent, slaveholders also addressed their appeals to already sympathetic audiences in an attempt to reestablish and defend consensus, not necessarily in the hope of altering the opinions of the abolitionists, who they believed were beneath contempt and not worthy of persuading. Thus, the abolitionist mail controversy of 1835 was 
characterized by rhetorical discourse that was devoted more to reaffirming community norms than to persuading the opposition.

Further, the new AASS strategy, as Amos Kendall decried, "perverted" the federal postal laws, which implicated the federal government in the abolitionist agenda. Indeed, W. Sherman Savage argued that the intrusion of abolitionist newspapers into the South aroused "unusual fear" precisely because "it made the national government an agent of the abolitionists who were doing so much to the detriment of the slaveholding section." Yet, in Clement Eaton's account of the crisis the AASS was a mere "minority group disliked both in the North and the South." And, while slaveholders were also a "minority group," Eaton argued that the federal government allowed the "virtual censorship of the mails," which indicated "the ascendancy of the Southern group in federal politics during the ante-bellum period." In other words, Eaton believes that the significance of the abolitionist mail crisis was to demonstrate that slaveholders had little to fear from abolitionists in $1835 .{ }^{10}$ This last view cannot withstand scrutiny, for while the result of the crisis was to reassert slaveholder control, slaveholders in 1835 believed that they had much to fear from the abolitionist propaganda.

Susan Wyly-Jones argued that the intrusion of abolitionists' newspapers in the carefully censored southern public sphere "re-ignited the slavery controversy in the South." She analyzed the anti-abolition sentiment in the months after the first AASS newspapers appeared in the South and discovered that in the three months after the initial "mail bombing" southerners held more than 150 anti-abolition meetings-in every slaveholding state save Kentucky and Delaware-where resolutions were passed condemning the mail. ${ }^{11}$ Additionally, by combing newspapers and census records she was able to identify many of the anti-abolition meeting leaders and attendees. She found that, as we might expect, the meetings were run by local elites, but that they were attended by all classes of white men. Wyly-Jones concluded that the meetings "functioned as ritualistic displays of white unity and the communal means of enforcing race control"; as such, the meetings "provide a revealing illustration of ways in which Southerners strove to unite the region socially and politically behind its domestic institution." 12 Therefore, the outpouring of southern sentiment in the wake of the abolitionist mail crisis can be considered the rhetorical means of defining and enforcing local community unity. Once again, the work of historians would suggest that the rhetorical appeals in the aftermath of the mail bombing were directed inward to sympathetic audiences, rather than outward to the larger American community.

Southern unity was necessary because the abolitionists' mail exacerbated preexisting and pervasive fears of slave insurrection. The wake of Nat Turner's 
1831 revolt and the more recent Mississippi insurrection scare had left southerners in fear of bloody slave revolts. In addition, the accounts of historians make it clear that slaveholders faced a newly determined antagonist in 1835 and that with their use of the post office strategy abolitionists could seemingly attack from a distance, out of the range of southern laws and community ostracism. Freehling is quick to point out that the relationship between southern "despotism and democracy" was an uneasy one in 1835: in order to keep slavery legal the slavocracy had to pretend that all white men were equal. The extension of the right of suffrage to all white men in the 1820s had given poor and middling whites the power to end slavery, and "nonslaveholding migrants were filling up western Maryland, western North Carolina, western Virginia, and even bits of western South Carolina ... These Westerners inside the Old East, like immigrants to the New West, wanted egalitarian republicanism for whites." ${ }^{13}$ Indeed, by the 1850 census only about 34 percent of southerners could claim to own any slaves at all. ${ }^{14}$ By 1860 only 1.4 percent of Americans in all states and territories held slaves $(393,975$ out of $27,303,009) .{ }^{15}$ Nonslaveholders forced state constitutions to be re-written in states like Virginia, where less enslaved western Virginia demanded that the Tidewater elite give up some of their power in state politics. In short, the slaveholding elite were losing power to non-slaveholders who were ambivalent about the benefits of maintaining slavery.

Yet, as Thomas Roderick Dew's 1832 Abolition of Negro Slavery makes clear, no one had a feasible plan for eliminating slavery. ${ }^{16}$ Southerners agreed that if slavery were to end, then slave owners would have to be compensated, but many believed that there was never going to be enough money for adequate compensation. Further, southerners feared the idea of emancipated blacks remaining in the South, but they believed that removal of the free black population was just as impossible as compensation. Therefore, since there was no viable method by which to achieve emancipation, slaveholders reasoned that it was just best to leave the subject alone. Northern abolitionists believed that these "constraints" on abolition were mere excuses and that slavery was morally wrong and thus demanded immediate emancipation.

In addition to the dangers to southern economic livelihood and personal safety, the conflicting societal demands of despotism and democracy were replicated in slaveholders' daily lives. Freehling describes the life of the slaveholder as a kind of "schizophrenia": "egalitarian republics required leaders to play unassuming convincer. Enslaved plantations required elites to exert overbearing coercion. The egalitarian and the elitist inside the same skin often popped out in the wrong realm. Elitists who trespassed onto egalitarians' turf were especially resented among white folk inside black-belt neighborhoods." 17 In response to the tensions inherent in the conflict between 
despotism and democracy, slaveholders sought control. Indeed, "southern masters' self-esteem, their self-respect, their very survival swung on the legitimacy of title.... To master oneself, to master others, to be master of all one surveys is so unlikely as to make the very concept suspect." 18 Slaveholders were at once convincer and coercer; democrat and despot; and they felt pressure from all sides: poor whites, enslaved blacks, free blacks, newly enfranchised non-slaveholders, and now northern abolitionists all required mastering, all required that slaveholders negotiate the schizophrenic demands of control. The abolitionists' newspapers therefore threatened elite slaveholders' ability to control their public sphere, to control the question of abolition, to control their slaves, to control free blacks, and to control poor whites.

In the fragile world of the despot's democracy the one thing that slaveholders could not tolerate was a loss of control, thus raising the question: How did slaveholders reassert and maintain control when confronted with the crisis of the abolitionists' mail appearing in the southern public sphere? In response to the impossibility of being able to master everyone, all of the time, the slaveholding elite responded to the new threat of abolitionism with coercive violence, rather than with democratic persuasion. Slaveholders' expert use of the norms of community obligation, enforced and supported by the rhetoric of honor, allowed them to reassert control over the abolition debate.

\title{
Locals Purify and Prevent Incendiary Mall: The Story of the Abolitionist Mall Crisis
}

\begin{abstract}
The post office in Charleston, S.C was forcibly entered on the night previous, by removing the inside shutter, and a bag, containing a large number of incendiary tracts and newspapers intended for distribution to the south and west, taken thence, of which it was understood that a bonfire was publicly to be made on the following night, at eight o'clock, without the limits of the city. ${ }^{19}$
\end{abstract}

The Niles Weekly Register reprinted the story of the mob of "two or three hundred citizens" who confiscated and destroyed the mail in Charleston on July $30,1835 .{ }^{20}$ Also reprinted in the day's news were reactions to the contamination and subsequent cleansing from the Charleston Southern Patriot and the Charleston Mercury and accounts from the Cincinnati Republican and the Columbus Democratic Press about an attempted white-led slave insurrection in Mississippi, which resulted in the lynching of "twenty-four negroes and twelve white men." Clearly with northerners mailing abolitionist propaganda and southern slaves and sympathetic whites colluding in a "horrible conspiracy," things were getting out of control in the South. The simultaneous defense of the cleansing and derision of the mailing by the 
Charleston Southern Patriot offers a glimpse into how the slavocracy viewed what was at stake in this controversy. First, the Patriot defended southern mob action with states' rights platitudes, "those states whose peculiar institutions are involved in hazard, must take the law into their own hands. Extreme cases require extreme remedies." Next, Charlestonians were reminded that they indeed had a duty to protect their body politic from poisonous outside contagions, "It never will do to allow our mails to be laden with these anarchical publications, while our citizens fold their arms and permit the poison to circulate through all the veins and arteries of society." Finally, lest Charlestonians get too used to taking the law into their own hands and begin wantonly prescribing extreme remedies without the sanction of the slavocracy, the Patriot recommended that such cleansing occur where it could be viewed by all:

Let it be performed in open day light and on the highway, and that persons of responsibility and weight of character be deputed to act in the name and for the good of the whole of the citizens. Let us, if the necessity is imposed on us of temporarily violating order, act with as little disorder as possible, and without the agency of large masses of men, who may become excited beyond the necessities of the case. ${ }^{21}$

The Patriot sought to fight two battles simultaneously: first, Charleston's elite needed the mass of its citizens to hate, fear, and destroy the incendiary mail, otherwise the abolitionists' propaganda might have its desired effect and the mostly middling and non-slaveholding South Carolinians might stop sympathizing with wealthy plantation owners and might seriously question the legitimacy of slavery. Thus, the Patriot labeled the abolitionists' mail "poison" that could not be allowed to "circulate" through the "veins and arteries of society" while citizens folded their arms in acquiescence. Citizens were told to think of their local community as an extension of their own bodies, and their local community-body needed protection from "anarchical publications." Outside anarchists threatened local community safety and citizens were obligated to defend themselves and the good order of society.

The Patriot's secondary concern was for their mostly middling and nonslaveholding citizens to understand that it was the proper role of "persons of responsibility and weight of character" to act for the interests of the whole, thus reaffirming that while the community was under attack from "anarchists," and while it was every citizen's duty to take "extreme measures" against the city's enemies, most citizens were only to continue to follow the orders of their betters and not allow themselves to become "excited" with lawlessness. The Patriot described the difficulty in unleashing the mass from the power of 
the federal law: the slavocracy still had to retain its control over the mass of the population, even as circumstance required encouraging that population to break the law. As the Patriot seemed to be clearly aware, there was a great deal of danger involved in the way that Amos Kendall had formulated community obligation. While citizens were told to flaunt their disrespect of national law because it had been perverted to attack their community, local law, also known as elite rule, was still to be respected.

Southern leaders relied on the norms of community obligation to maintain order and to control potential forces of anarchy in both the North and South. Southern leaders alternately cajoled, threatened, and enlisted the aid of northern abolitionists, postmasters and citizens, and of southern slaveholders and non-slaveholders. Slaveholders initially insisted that abolitionists admit their own guilt and stop the mailing. When this strategy failed, they demanded that the North stand up and actively defend southern honor. When this last strategy failed, slaveholders ordered violent retribution. It is by examining these differing appeals that we gain a better understanding of how the norms of community obligation could serve the needs of slave masters in their efforts to reassert control and prevent anarchy.

\section{Appeals to the North}

The simplest way to end the problematic mail would have been for the abolitionists to agree to stop the presses; however, as much as both southerners and northerners condemned the actions of these "anarchists," "fanatics," and "detestable villains" they would not agree to put an end to production. The New York Herald reported that the Anti-Slavery Society responded to public pressure to stop the mail with an unequivocal negative: "they passed a resolution declaring, peremptorily that they would not abandon their right of transmitting, through the post office all such tracts and papers as they choose to flood over the country." 22 In fact they did not stop printing and mailing their newspapers and pamphlets throughout the nation. According to the Fourth Annual Report of the American Anti-Slavery Society, from May 1836 to May 1837 (the year after the first mailings began) 9,000 copies of The Anti-Slavery Magazine, 130,150 copies of The Slave's Friend, 103,000 copies of The Anti-Slavery Record, 189,000 copies of Human Rights, and 217,000 copies of The Emancipator were published and mailed throughout the country. ${ }^{23}$

New printing technologies meant that abolitionists had a new and "unnatural" tool for spreading their "detestable villainy." For example, by December 22, 1835, Virginia Congressman John Jones would express his constituents' fears of this new power in a floor speech abstracted in Gales and Seaton's Register of Debates in Congress: 
Was it not known to every gentleman upon this floor that numerous abolition societies had been formed in the eastern and northern States, frowned upon, indignantly frowned upon, he believed, by the intelligent, the well-informed, and the respectable portions of these communities. But could they shut their eyes to the fact, that these societies existed, that they had gone on to collect large sums of money, and had put into operation printing presses, which were worked by steam? Yes, sir, worked by steam, with the open and avowed object of effecting the immediate abolition of slavery in the Southern states. That by means of these two great revolutionizers of the world, he meant steam power, and the press, they had caused to be printed, and by means of the public mails, circulated throughout the slaveholding States, large numbers of newspapers, pamphlets, tracts, and pictures, calculated, in an eminent degree, to rouse and inflame the passions of the slaves against their masters, to urge them on to deeds of death, and to involve them in all the horrors of a servile war. ${ }^{24}$

As Jones's speech attests, the southern slavocracy viewed the raising of money, the printing of abolitionist papers, and the mailing of them into the South as both an intentional and a coordinated act of aggression. And while his fear of the use of new communication technologies may seem irrational, it may also be viewed as a legitimate response to fears of modernity and the attendant further ebbing of the slaveholders' ability to control everything and everyone around them. The kind of complete mastery necessary to ensure the perpetuation of the southern way of life meant that their public sphere had to be closely guarded against "outside" perspectives, lest slaves, sympathetic whites, and free blacks begin to think like the outsiders from the "Eastern and Northern states." What could be worse than abolitionists, whom the "respectable" part of society "frowned upon," seizing control of these new technologies and using them in ways that no one had ever conceived of before while good men "shut their eyes?" What else could these "miserable fanatics" do, if they could do this and the South was powerless to stop them? These questions not only boggled the mind, but they also led southerners to rigidly defend their public sphere from the perversion of these unnatural technologies.

The next step in attempting to stop the mail was to prevent the newspapers from being shipped from New York down South. To aid in this plan, Charleston Postmaster Alfred Huger enlisted James Monroe's son-in-law, New York Postmaster Samuel L. Gouverneur. Gouverneur agreed that the mail was dangerous and requested the American Anti-Slavery Society to stop sending it to the South-to no avail. He therefore decided that he would "aid in preserving the public peace" by censoring the abolitionists' mail himself. In making 
this decision Gouverneur solicited the opinion of Amos Kendall, who wrote that "the postmaster general has no legal authority, by any order or regulation of his department, to exclude from the mails any species of newspapers, magazines or pamphlets." But, even though Kendall believed that he was powerless to stop the mail by General order, he still had "no hesitation in saying, that I am deterred from giving any order to exclude the whole series of abolition publications from the southern mails only by want of legal power; and that if I were situated as you are, I would do as you have done."25 Undeterred, the AntiSlavery Society merely diverted their mailings from New York to Philadelphia and other places and began to try to hide the contents in seemingly innocuous packages. Hazard's Register of Pennsylvania reports that on August 25, 1835, newspapers of the "most incendiary and inflammatory character" were hidden in a "large wooden box, apparently filled with dry goods." Upon discovery, the helpful dock workers destroyed the incendiary newspapers. ${ }^{26}$

Aside from obliging postmasters and dock workers, southerners also received the support of anti-abolitionist citizens in Philadelphia, New York City, Albany, and Connecticut, among others. For example, Bostonians assembled in Faneuil Hall—the "Cradle of Liberty" - to "let a manifesto go forth declaratory of our sentiments, as to the rights of the south, and of our abhorrence of the conduct of those combinations, which, under the name of philanthropy, are encouraging the worst of all possible calamities which can befal [sic] a nation, A CIVIL AND A SERVILE WAR." 27 Slaveholders greeted news of northern sympathy with skepticism: they demanded action not words. For example, one Georgian made the distinction between words and action explicit, "These northern and eastern gentlemen are very shrewd and artful. Their interest is their grand passion. ... Is it not abundantly proved by all the resolutions and reservations at Boston, New York and other places?" He had no trouble answering his own question, "'Words, words, words,' are all we are to have, and they will not at all restrain [Arthur] Tappan and his associates. We are told the ABOLITIONISTS are few in numbers. It is not so. They constitute a very large majority of all the people." ${ }^{28}$ Despite the fact that it was precisely the force of words that the slaveholders feared most—-the words written in the abolitionists' newspapers-our anonymous citizen of Augusta, Georgia, berated northern anti-abolitionists for their lack of supportive violence.

Slaveholders feared the power of words; yet, words were not enough to combat words. Slaveholders believed that the abolitionists' words were violence; they therefore demanded that violence be met with violence. As the fanatical abolitionists were thought to abound in the North another similarly antagonistic slaveholder-this time from Virginia-dared the North to do more to protect the South: 
Had a prophet spoken it, the last sentiment expressed by the Star could not be more true: "The abolitionists must be put down or they destroy the union." Choose they! It is in their power to suppress them by legitimate and constitutional means. Some of their presses consider this, menace, threat, hectoring, bravado! They little know the state of southern feeling! They little know that the press in the south is far below the tone of general excitement. They cannot know; it is impossible they should know without residence, the cause there is for this excitement. ${ }^{29}$

Building on the sentiment expressed by other slaveholders, this anonymous Richmond Whig author demonstrated the categorical thinking in operation. There were no gray areas: Americans were either with the South, slavery, and safety or they were with the abolitionists, anarchy, and aggression. Thus, slaveholders demanded that Americans choose. Such ways of thinking drove some northerners to protest and petition the South in the hope that they would understand that the North was on their side, while such thinking also drove slaveholders to demand that northerners prove just how loyal to the South they were. It seems as though nothing short of extraditing abolitionists for southern lynching would have satisfied the "actions not words" mentality of southerners in 1835 . For how could mere words satisfy the "general excitement" of "southern feeling?" In fact, how could any outsider from the North even know the "tone" of feeling that this incendiary mail had caused? The threat to southerners' safety and property was palpable to those who lived among the slaves and they knew that this threat must be controlled.

Slaveholders remained unconvinced that northerners understood the precise danger that the abolitionists had unleashed upon them. Thus, one strategy for turning promises of northern support into action was to threaten a "suspension of commercial intercourse with the northern states." 30 Some cities like Lowell, Massachusetts were banished from trading with the South because they openly supported the abolitionists. Other cities such as New York were threatened with boycotts because southerners did not like the way that they had framed their derision of the abolitionists. The New York Herald responded to such threats with further protestations of sympathy and support for slaveholders. "Where there is one abolitionist among the merchants north of the Potomac," wrote the Herald, "there are one hundred against the fanatics. A general commercial non-intercourse would involve friends as well as foes. Besides, this is a political not a commercial question-it is a question of state rights, and should be so considered." ${ }^{31}$ The Herald correctly understood the best way to show their support of the slavocracy_by adopting their talk of "fanatics" and their categorical language of friends and foes-but, the Herald mistook the question to be one merely of states' rights. The question was personal as much as it was political and commercial; slaveholders understood that 
this was a question of state autonomy, of economic necessity, and most explicitly, a question of local safety and control. Northerners remained unpersuasive in their attempts to mollify slaveholders. Southerners did not believe that outsiders could comprehend the horrible threat to their safety caused by the abolitionists' newspapers' intrusion into their public sphere. Simply, the South did not trust that the North would help to protect the South-such distrust frayed the fragile threads of loyalty that constituted the imagined national community and concomitantly caused southerners to focus their defensive energies within their local communities.

\section{Appeals to the South}

While slaveholders attempted to garner more action and less talk from the North, it was less necessary to explain the dire consequences of freely circulated abolitionist newspapers in the South. Southerners-slaveholders and non-already understood the danger that these newspapers had introduced into their lives. Yet, as the Charleston Southern Patriot had argued, southern community obligation required that the mass of southerners continue to follow the lead of their local "gentleman of character," and not become "excited with lawlessness." Therefore, because the slavocracy needed to reassert its control over free and enslaved blacks and poor whites, appeals to fellow southerners asked them to unite against the incendiary mail, to maintain vigilance in suppressing the mail, and to threaten outsiders with the full extent of southerners' rage. These appeals can be understood as constituting the mandates of community obligation where loyalty is paramount and ostracism is shameful.

The first slaveholder strategy for appealing to southerners was to present a unified front for southern opposition. Yet, as Freehling notes, it was difficult to claim unity when there was not "A South." Differences between the barely enslaved Border South states, the more enslaved Middle South states, and the almost entirely enslaved Deep South states resulted in different crop production, different power structures, different fears of slave insurrection, and hence, different demands for control. The coordination of a united southern response was crucial both for mitigating the threat of the abolitionists' propaganda and for demonstrating the South's strength to its abolitionist foes. Further, according to Freehling, people began to believe that "the idea of abstract liberty, once agitated in the North and mailed to the South, would turn some slaves' heads, trouble some slaveholders' consciences, [and] inspire liberty-loving non-slaveholders North and South to turn against liberty's curse." ${ }^{32}$ In response to the fear that the incendiary mail would lead some southerners to question the legitimacy of slavery, slaveholders attempted to join the disparate interests of the South in opposition. 
For example, Niles Weekly Register of August 8, 1835, contained an enlightening history of the community ritual of vigilante justice known as "Lynch's Law," followed by a reprint of a call for southern unification against the "detestable villainy" of the abolitionist mailings. "Concurrent testimony," the National Intelligencer reported, "from different parts of the southern states, satisfy us that the miserable fanatics, few in number, as they are, who manufacture the abolition journals, have flooded the mails with them, to the just exasperation of the south, and to the great peril of the whole slave population of their country." ${ }^{33}$ The Charleston Mercury of July 30, 1835, warned that the incendiary newspapers were approaching and to whom they were addressed, in order to "put our southern friends on their guard, and to warn them of the insidious measures now in a course of execution for their destruction." 34 Such warnings were appreciated: Committees of Safety passed resolutions all over the South, which formally required postmasters to warn citizens whenever incendiary mail appeared in town. Local communities hoped that these warnings would cut off the abolitionists' access to the distributive power of the post office, thereby allowing local communities to control their public sphere. Importantly, the question debated at these meetings was not whether to abolish slavery, but how best to silence those who would wish to advocate for the abolition of slavery. In short, while there might not have been "A South" as Freehling argued, southern leaders were united in their fear of the open discussion of abolition and this fear helped disparate southern communities to join together against the force of dialogue.

The second slaveholder strategy for appealing to southerners was to use the power of local law to force newly united citizens to be vigilant in their opposition to federal law. For example, the uproar over the newspapers in Charleston caused the city to call a public meeting — less than a week after the first mailings- "at which the subject of the interference of northern abolitionists, in the rights of southern citizens, was warmly discussed."35 The resolutions passed in Charleston were the first of their kind, were widely reported in the press, and were adopted by at least 150 other communities around the South; therefore these resolutions merit consideration.

The city of Charleston adopted the following "by acclamation": First, "That we hold any attempt to impair the rights of property in our slaves, as guaranteed by the Constitution ... a a a wanton violation of our political compact, and destructive of the whole frame of our government." Second, "That we have a just claim on all the non-slave holding States for the enactment of suitable and efficient laws, to repress and put down by adequate penalties, all incendiary or seditious associations, whose avowed purpose is to disturb our peace and to excite insurrection among our slaves." Third, Charlestonians asked for "Captains of Steamboats" to "exercise the utmost vigilance in detecting any 
emissaries of the abolition societies" and for southerners to cease business with those who did not comply. Finally, Charleston demanded that the "Post Master General," Amos Kendall, "use all the powers vested in him to prevent the transmission and the delivery of all printed papers, suspected of a tendency to produce or encourage an insubordinate or insurrectionary spirit among the slaves of the South." 36

The resolutions assumed that the twin powers of constitutional and local community law should be used to threaten abolitionists and their sympathizers. The "insurrection" that Charleston's citizens were fighting against was not of local citizens disobeying federal law, but of outsiders disobeying local law. Resolutions such as these were also passed in Georgia, North Carolina, and Virginia, among other states. ${ }^{37}$ Resolutions codified public opinion, gave southern citizens clear local laws to follow, and warned outsiders that the South would not allow the infiltration of its public sphere. The safety of the local laws required that the South be united in condemning the mail and also required that citizens be vigilant in protecting and defending their united perspective. Ultimately, however, slaveholders relied on threats of violence to accomplish their goal of reasserting control.

The third slaveholder strategy for appealing to southerners was the use of threats. Mostly these were threats of physical violence, but there were also threats of ostracism, and negative consequences for the slaves whom the abolitionists were hoping to liberate. Further, slaveholders threatened northerners that union and safety required that they control the abolitionists. Richmond, Virginia's Committee of Safety Resolutions, for example, admonished "our northern fellow citizens, that as they value the blessings bestowed by our constitution, and the continuance of the union; as they estimate the peace of our country; as they would guard against evil commotion, war and bloodshed, to make all within their boarders, and under the influence of their laws, desist from their mad and wicked schemes." ${ }^{38}$ But, while northerners were threatened with discord and disunion, those who harbored abolitionist sentiment in the South would suffer more personally.

For example, on the night of July 30,1835, when Charlestonians confiscated and destroyed the incendiary mail, they also warned of the consequences of abolitionist sentiment by ordering that the "effigies of Arthur Tappan, Dr. Cox, and W. L. Garrison, leading abolitionists," be "publicly suspended." The Niles Weekly Register reported on August 22, 1835, that Charleston offered a reward of $\$ 1,000$ "for the apprehension and conviction of any person bringing into this city, an incendiary paper or publication"; that "a man named Brady" in North Carolina and "a man named Pugh" in Virginia were arrested and charged "with 'tampering' with the slaves"; that a "suspicious" man in Chestertown, Maryland was arrested after having been discovered to have 
been "in conversation with the negroes"; and finally, that "a man named Robert Bell was hung in Clinton, Mississippi-as an 'insurrectionist." 39 Similarly, the Washington Globe reported that a "man named Crandell ... was taken up in Georgetown in this district, night before last, by the police officers of this city, and put in jail, under the charge of circulating Tappan, Garrison \& Co.'s papers, encouraging the negroes to insurrection." ${ }^{40}$ These accounts demonstrate that southerners were serious about the threats caused by abolitionists, and that they were just as serious about their threats to abolitionists and their sympathizers. ${ }^{41}$ The message was clear: anyone caught doing anything suspicious would be surely and swiftly subject to punishment. By proving the power of local law to control the actions of its citizens, southerners also proved that they could protect their interests without federal laws- that both community interest and community justice were superior to federal law.

Despite the fact that slaveholders knew how to use community obligation to control those around them, a like-minded southerner occupied the White House in 1835 and he was not the kind of president who could let something like the abolitionist mail crisis pass without getting personally involved. Immediately after the first abolitionist mail bombing of the South, President Andrew Jackson wrote to advise Amos Kendall on how the matter should be handled. Following the code of "community obligation," Jackson thought that it was best to let southern neighbors pressure other southerners to reject the publications. "We can do nothing more than direct that those inflamatory [sic] papers be delivered to none but who will demand them as subscribers," wrote Jackson. "In every instance the Postmaster ought to take the names down, and have them exposed thro the publik [sic] journals as subscribers to this wicked plan of exciting the negroes to insurrection and to massacre." Jackson's response was typical of other southerners-locals should take care of the problem at home with unification, vigilance, and threats. Jackson believed that with such publicity "every moral and good citizen will unite to put them in coventry, and avoid their society. This, if adopted, would put their circulation down everywhere, for there are few so hardened in villainy, as to withstand the frowns of all good men." ${ }^{2}$

Jackson had misread the situation. For, while slaveholder threats and vigilance had already had a prohibitive effect on southern demands for abolitionist reading material, he seems to have overlooked the fact that southerners had not actually subscribed to the newspapers. Rather, abolitionists sent newspapers that few wanted to read, or to have anyone else read, for that matter. ${ }^{43}$ It was this willful intrusion into the southern public sphere that slaveholders most objected to; the slavocracy simply did not want the question of abolition to be publicly discussed. And while the mass of southerners understood that this topic was off-limits, outsider abolitionists were using newspapers and the 
post office in an attempt to force the topic onto the southern public agenda. Because the abolitionists had preyed on a loophole in the federal laws to infiltrate the southern public sphere- "perverted" the law as Kendall had written-slaveholders hoped that the federal government would protect their interests by eliminating abolitionists' access to the South through the postal system.

Therefore, because the norms of community obligation could not reach northern abolitionists who were in no way a part of the southern community, Jackson made the issue a federal concern in his December 7, 1835, message to Congress. His outrage at the mail bombing was evident when he described it as "destructive of the harmony and peace of the country, and so repugnant to the principles of our national compact, and to the dictates of humanity and religion." ${ }^{44}$ Like Congressman Jones of Virginia, President Jackson found the country to be "fortunate" because of the professed anti-abolitionist sentiment expressed by "the good sense, the generous feeling, and the deep-rooted attachment of the people of the non-slaveholding States of the Union." But, like other slaveholders who had called for more action and less talk, Jackson found this anti-abolitionist talk lacking.

But if these expressions of the public shall not be sufficient to effect so desirable a result, not a doubt can be entertained that the non-slaveholding States, so far from countenancing the slightest interference with the constitutional rights of the South, will be prompt to exercise their authority in suppressing, so far as in them lies, whatever is calculated to produce this evil. ${ }^{45}$

Just as other slaveholders had done, Jackson called upon the North to take action to censor and to prohibit the association of abolitionists in order to secure southern safety. He asked Congress to pass "such law as will prohibit, under severe penalties, the circulation in the southern States, through the mail, of incendiary publications intended to instigate the slaves to insurrection." Even though Jackson supported the use of local community law-both North and South - to control the bad mail, like other southerners he hoped that the federal government would assume its responsibility, its "great trust," and close abolitionists' access to the southern public sphere. He argued that doing so would "preserve inviolate the relations created among the States by the Constitution." ${ }^{\prime 6}$ Thus we see an exact replica of slaveholder outrage as printed in local newspapers and in Committee of Safety Resolutions: abolitionists had violated southern rights and safety and while the North may have feigned support for slaveholders, direct action was required to preserve the Constitution and the Union. President Jackson clearly understood the mandates of community obligation. 
However, Jackson urged that national legislation relieve the South of the added burden of defending its public sphere and in so doing he unwittingly set in motion events that would result in the ultimate, if nominal, supremacy of outsider perspectives on this question. The House of Representatives and the Senate both considered resolutions consistent with Jackson's message. The House sent the question to the Committee on Post Office and Post Roads, which buried it, never to be debated by the Committee of the Whole. The Senate, however, eventually debated a censorship bill, but did not pass it. Rising in its place was a bill which "prohibited any postmaster, under severe penalty, from unlawfully detaining in his office any letter, package, pamphlet, or newspaper and refusing to deliver the same to the person to whom it was addressed." 47 Jackson refused to sign the bill into law for seven months, but eventually acquiesced. Southern states refused to enforce the bill and it remained a "dead letter law" until after the Civil War.

\section{The RHetoric Of HonOR}

The abolitionist mail crisis of 1835 illustrates how the pressure of community obligation could be used to mitigate the dangerous threat of outside "poison" from disrupting the carefully ordered system of control that was slaveholder mastery. But, the rhetorical use of community obligation could only work on those actually within the community. Appeals to outsiders were significantly more violent and were couched in the language of war. ${ }^{48}$ Robert L. Ivie has carefully examined how appeals to victimage, vilification, and savagery in war rhetoric allow for justifications of "reluctant belligerence" based on the logic of "necessary evil." ${ }^{49}$ For example, Ivie has argued that a "just war" must be presented as a "reluctant war": "That is, a people strongly committed to the ideal of peace, but simultaneously faced with the reality of war, must believe that the fault for any such disruption of their ideal lies with others." The scapegoat-enemy is "portrayed as a savage i.e., as an aggressor, driven by irrational desires for conquest, who is seeking to subjugate others by force of arms." Further, the enemy's actions are portrayed as "coercive, irrational, and aggressive attempts to subjugate a freedom-loving, rational, and pacific victim." Ivie believes that the categories of "force vs. freedom, irrationality vs. rationality, and aggression vs. defense permeate the substance and style of the call-to-arms throughout American history," and therefore, by his logic we would expect to find them in use in antebellum slaveholder rhetoric. ${ }^{50}$

Indeed, slaveholders believed that "miserable fanatics," who were hoping to foment "insurrection," had attacked the South; as such, slaveholders viewed themselves as defending their freedom from the force of irrational aggressors. One Charlestonian, for example, could not understand why non-slaveholding 
states were "designated the free states, thus plainly implying a taunt on the slaveholding states." He asked his fellow southerners if they would "remain passive under these insults and not notice them in the way of rebuke and of retort if necessary?" ${ }^{51}$ Clearly, his answer was no, the South should not remain passive and allow northerners to portray southerners as less free. He was not alone. Published and republished throughout the country, Amos Kendall's demand for community loyalty - "we owe an obligation to the laws, but a higher one to the community in which we live"-represented the tenor of the slaveholder response to abolitionist aggression: unify southern communities, threaten abolitionist outsiders, and vigilantly maintain southern order. In short, slaveholders in 1835 believed that they were fighting a just war, which helps us to comprehend the violent response to the abolitionists' newspapers within their midst.

Even though slaveholders cast their war against abolitionists as "just," they did not portray themselves as "reluctant" belligerents. Slaveholders were not "unwilling victims" of abolitionist aggression, but were, as they repeatedly declared, fearless warriors fighting in defense of their right to control their public sphere. What could explain this radical departure from the common strategy of positioning oneself as the victim? Certainly slaveholders portrayed abolitionists as the traditional scapegoat in their attempts to unify southerners to vigilantly protect their public sphere, so why would they radically diverge from the rhetoric of victimage? The answer to this conundrum may lie in the "culture of honor" prevalent among the antebellum southern gentry.

As Joanne B. Freeman argued in Affairs of Honor, the "code of honor" was neither unique to the South nor was it invented in America. ${ }^{52}$ On the contrary, as the work of anthropologists John G. Peristiany and Julian Pitt-Rivers demonstrates, honor and grace have long functioned as societal regulators. ${ }^{53}$ Yet, according to Bertram Wyatt-Brown, while the culture of honor had long defined acceptable relations among men in the antebellum South it was both more important and more violent: "the darker, more unpleasant aspects of Southern life betokened the continuation of the archaic forms, kept alive by the exigencies of an inhospitable, dangerous world where masters had to rule in fear." Southern honor was "an encoded system, a matter of interchanges between the individual and the community to which he or she belonged. Meaning was imparted not with words, but in courtesies, rituals, and even deeds of personal and collective violence." 54

Honor must be understood in relation to its counterpart: shame. "An individual," according to Wyatt-Brown, "was expected to have a healthy sense of shame, that is, a sense of his own honor. Shamelessness signified a disregard for both honor and disgrace." ${ }^{55}$ Therefore, when Amos Kendall asserted the primacy of community obligation and Andrew Jackson believed 
that the abolitionist mail crisis could easily be resolved by shaming the recipients of the propaganda - "there are few so hardened in villainy, as to withstand the frowns of all good men," he had said-they demonstrated the prevalence of the culture of honor in southern responses to the abolitionists' mail. The norms of community obligation - the transactional relationship of honor and shame between a citizen and his or her community-and the power of public shame should have prevented all but the most "hardened in villainy" from receiving the newspapers. Jackson's simple solution for resolving the mail crisis was to expose recipients of the papers to public shame, but while this solution addressed the problem of freely circulating abolitionist propaganda, it did nothing to resolve the larger problem that slaveholders faced: reasserting control.

As outsiders, abolitionists had attempted to impose shame on slaveholders and in so doing had threatened elite control. This point is crucial for understanding the violent slaveholder response because, as Wyatt-Brown notes, southerners negotiated the culture of honor with three related judgments: first, "the evaluation of the public"; second, "self-assessment before the public"; and finally, "a judgment based on the behavior of the claimant." In other words, a person's, a family's, or a community's good reputation was the basis of acceptance, status, and privilege in the South. Therefore, a good reputation was worth fighting for; the number of "affairs of honor" in the southern states attests to the fact that southerners took the code seriously enough to risk death. ${ }^{56}$ As southern leaders were well aware, the South as a whole had been shamed by abolitionists who asserted that slavery was debased. By mailing the pamphlets into the South, abolitionists impugned the honor of the South and held it up as a land of shameless libertines who were disrespectful of the morals of humanity. Therefore, perhaps the most important feature of the code of southern honor was the relationship between community sanction and honor because, quite simply, "when shame was imposed by others, honor was stripped away." 57

In response to public shaming, southerners knew that they must fight in order to regain their honor and retain their status. A fight for honor need not, indeed could not, be justified through a rhetoric of victimage; a fight for honor could only be presented as an indignant, willing defense of reputation and status. The claims of the enemy would have to be minimized and trivialized, even as the enemy was used as a scapegoat to unify community opinion in support of the dishonored party's reputation. Abolitionists were "miserable fanatics," or contemptible and irrational enthusiasts. Miserable fanatics could only be destroyed in defense of honor, not persuaded or dismissed. The slavocracy had no doubt that the South benefited from their leadership and from slavery, so there was no threat that the abolitionists' newspapers would cause 
slaveholders to believe that they had been legitimately shamed. But, because honor was so tied to reputation and community, slaveholders still had to perform a defense of their honor and its attendant privileges in order to retain power and control..$^{58}$ Hence, the violent reaction of the South-the willing belligerence - was a defense of personal and regional honor in the face of an outsider shaming. The slaveholders' successful use of the rhetoric of honor not only allowed them to reassert control over their local communities, but because it was so successful in unifying southern opinion and behavior, it also allowed them to reassert control over national abolition debates and policies-no small feat, to be sure.

The main features of the rhetoric of honor can be extrapolated from the story of the slaveholder response to the abolitionist mail campaign of 1835 . First, persuasion is directed inward to local community members who are asked to unite and to vigilantly and violently defend community norms. As Celeste Condit's work would suggest, the rhetoric of honor is not devoted to "rational explanation," but to "rituals reconfirming shared values"; in other words, it is epideictic rather than deliberative. ${ }^{59}$ The second, and closely related, feature of the rhetoric of honor is that it is designed to silence enemies. Abolitionists were enemies and enemies were outsiders who were beyond the reach of community norms, obligation, or consensus. Persuasion was reserved for community insiders who could reaffirm the honor of the accused and, thus, enemies could only be engaged with violence, not words. The third, and final, feature of the rhetoric of honor is that it is meant to restore reputation and status above all else-it is epideictic violence: discourse that uses the mandates of community obligation to punish outsiders and control insiders.

The parallels between the rhetoric of honor as epideictic violence and the actual violence of the code duello are obvious: if shamed, then honor can only be restored by demanding satisfaction. Slaveholders knew that to restore their honor abolitionists would have had either to admit their own guilt, fight, or run away. Slaveholders initially insisted that abolitionists admit their own guilt and stop the mailing. When this strategy failed, they demanded that the North actively defend southern honor. When this last strategy failed, slaveholders ordered violent retribution. In each of these steps slaveholders insisted, demanded, and ordered abolitionists and northerners; they always assumed the position of indignant superior, never did they position themselves as supplicant or peer. In short, they demanded that the affront to their honor be rectified on their own terms, thus reaffirming their local reputation and status in tone, style, and violence.

Slaveholders' expert use of the norms of community obligation, supported by the rhetoric of honor, allowed them both to reassert control over the abolition debate and to retain their status and privilege. But what can be said of 
the ethical implications of the rhetoric of honor? When only friends can be persuaded and enemies must be silenced, then there is no potential for real democracy. When a difference of opinion is deemed "incendiary," then there can be no debate, no freedom of speech, and no opportunity for deliberation. When the culture of honor trumps democracy and epideictic violence is the only acceptable form of speech, then authoritarian regimes prevail. The rhetoric of honor certainly is not limited to slaveholder defenses of slavery; rather it has, and does still, permeate the American political community. Certainly the rhetoric of honor does not always lead to repressive forms of speech. But, because oppression is always a possibility, scholars and citizens should closely examine how the rhetorical embodiment of the culture of honor functions in American public discourse.

\section{NOTES}

1. Postmaster General Amos Kendall to Alfred Huger Postmaster of Charleston, South Carolina, August 4, 1835, reprinted in Niles Weekly Register, August 22, 1835, 448. Emphasis in original.

2. See "Detestable Villainy" from the National Intelligencer and the Southern Patriot both of July 29, 1835.

3. William W. Freehling, The Road to Disunion: Secessionists at Bay 1776-1854 (New York: Oxford University Press, 1991), 291.

4. Roughly four percent of the American public owned slaves in 1835; yet, it is clear that slaveholders controlled national politics in excess of their minority status between 1787 and 1861. Indeed, not only were "five of the first seven presidents . . slaveholders," writes William Lee Miller, but "for thirty-two of the nation's first thirty-six years, forty of its first forty-eight, fifty of its first sixty-four the nation's president was a slaveholder. The powerful office of Speaker of the House was held by a slaveholder for twenty-eight of the nation's first thirty-five years. The president pro tem of the Senate was almost always a slaveholder. The majority of cabinet members and-very important—chief justices of the Supreme Court were slaveholders." William Lee Miller, Arguing About Slavery: John Quincy Adams and the Great Battle in the United States Congress (New York: Vintage, 1998), 13.

5. Lyon Rathbun, "The Debate over Annexing Texas and The Emergence of Manifest Destiny," Rhetoric \& Public Affairs 4 (2001): 459-493; Susan Zaeske, "Signatures of Citizenship: The Rhetoric of Women's Antislavery Petitions," Quarterly Journal of Speech 88 (2002): 147-168; Susan Zaeske, Signatures of Citizenship: Petitioning, Antislavery, and Women's Political Identity (Chapel Hill: University of North Carolina Press, 2003); Cal M. Logue, "Transcending Coercion: The Communicative Strategies of Black Slaves on Antebellum Plantations," Quarterly Journal of Speech 67 (1981): 31-46; Michael William Pfau, "Time, Tropes, and Textuality: Reading Republicanism in Charles Sumner's 'Crime Against Kansas,” Rhetoric \& Public Affairs 6 (2003): 385-414; Gary S. Selby, "Mocking the Sacred: Fredrick Douglass's 'Slaveholder's Sermon' and the Antebellum Debate over Religion and Slavery," Quarterly Journal of Speech 88 (2002): 326-341; William E. Wiethoff, "The Nature and Limits of Slave Insolence in the American South," Quarterly Journal of Speech 87 (2001): 197-207; David Zarefsky, "Rhetorical Interpretations of the American Civil War," Quarterly 
Journal of Speech 81 (1995): 108-138; David Zarefsky, "The Continuing Fascination with Lincoln," Rhetoric \& Public Affairs 6 (2003): 337-370; Stephen H. Browne, "Like Gory Spectres': Representing Evil in Theodore Weld's American Slavery As It Is," Quarterly Journal of Speech 80 (1994): 277-292; E. Culpepper Clark, "Pitchfork Ben Tillman and the Emergence of Southern Demagoguery," Quarterly Journal of Speech 69 (1983): 423-433; Donald K. Enholm, David Curtis Skaggs, and W. Jeffrey Welsh, "Origins of the Southern Mind: The Parochial Sermons of Thomas Cradock of Maryland, 1744-1770," Quarterly Journal of Speech 73 (1987): 200-218; V. William Balthrop, "Culture, Myth, and Ideology as Public Argument: An Interpretation of the Ascent and Demise of 'Southern Culture,"” Communication Monographs 51 (1984): 339-352; Kirt H. Wilson, "The Racial Politics of Imitation in the Nineteenth Century," Quarterly Journal of Speech 89 (2003): 89-108.

6. William W. Freehling, The Road to Disunion, 70, 290-295.

7. Bertram Wyatt-Brown, “The Abolitionists' Postal Campaign of 1835," Journal of Negro History 50 (1965): 227-238, 227.

8. Wyatt-Brown, “The Abolitionists' Postal Campaign of 1835," 229.

9. W. Sherman Savage, "Abolitionist Literature in the Mails, 1835-1836," The Journal of Negro History 13 (1928): 150-184, 150.

10. Clement Eaton, "Censorship of the Southern Mails," The American Historical Review 48 (1943): 266-280, 266-267.

11. Susan Wyly-Jones, "The 1835 Anti-Abolition Meeting in the South: A New Look at the Controversy over the Abolition Postal Campaign," Civil War History 47 (2001): 289-309. Richard R. John, Spreading the News: The American Postal System from Franklin to Morse (Cambridge: Harvard University Press, 1995).

12. Wyly-Jones, "The 1835 Anti-Abolition Meeting in the South," 293.

13. Freehling, Road to Disunion, 164. For more on the extension of the franchise see: Alexander Keyssar, The Right to Vote: The Contested History of Democracy in the United States (New York: Basic Books, 2000); Chilton Williamson, American Suffrage: From Property to Democracy 1760-1860 (Princeton: Princeton University Press, 1960); M. D. Naar, The Law of Suffrage and Elections (Trenton: Naar, Day \& Naar, 1880); Kirk H. Porter, A History of Suffrage in the United States (New York: Greenwood Press, 1918); and Dudley O. McGovney, The American Suffrage Medley: The Need for a National Uniform Suffrage (Chicago: University of Chicago Press, 1949).

14. Freehling, Road to Disunion, 18.

15. Data gathered from the 1850 Untied States Census.

16. Thomas Roderick Dew, “Abolition of Negro Slavery," American Quarterly Review 12 (1832): 189-265.

17. Freehling, Road to Disunion, 39.

18. Freehling, Road to Disunion, 41.

19. Niles Weekly Register, August 8, 1835, 403.

20. See Clement Eaton, "Mob Violence in the Old South," Mississippi Valley Historical Review 29 (1942): 351-370; Edwin A. Miles, “The Mississippi Slave Insurrection Scare of 1835," The Journal of Negro History 42 (1957): 48-60; David Grimsted, "Rioting in Its Jacksonian Setting," The American Historical Review 77 (1972): 361-397.

21. Charleston Southern Patriot, reprinted in Niles Weekly Register, August 8, 1835, 403.

22. New York Herald, reprinted in Niles Weekly Register, August 15, 1835, 410. 
23. American Anti-Slavery Society, Fourth Annual Report (New York, July, 1837), 348.

24. John W. Jones, December 22, 1835, "Speech on the Floor of the House of Representatives," Gales \& Seaton's Register of Debates in Congress (Washington: Gales \& Seaton, 1825-1837), 2035.

25. Amos Kendall to Samuel L. Gouverneur, August 22, 1835, Richmond Enquirer, September 4, 1835,4 . The letter was reprinted in at least five other papers. While Kendall applauded Gouverneur's purging of the mail, the New York postmaster himself appeared to have been honestly torn about the proper course of action, writing to the abolitionists that he assumed the "responsibility in the case you have made with me, and to the law and my superiors will hold myself accountable."

26. Hazard's Register of Pennsylvania, August 25, 1835.

27. Boston Atlas, August 7, 1835.

28. Anonymous, Augusta Chronicle, September 12, 1835.

29. Anonymous, Richmond Whig, October 3, 1835.

30. Richmond Whig, October 3, 1835.

31. New York Herald, October 3, 1835.

32. Freehling, Road to Disunion, 293.

33. Niles Weekly Register, August 8, 1835, 402.

34. Charleston Mercury, July 30, 1835.

35. Atkinson's Saturday Evening Post, August 15, 1835, 2.

36. Atkinson's Saturday Evening Post, August 15, 1835, 2.

37. There were more than 150 anti-abolition meetings in the South from August to December 1835. See Wyly-Jones, "The 1835 Anti-Abolition Meeting in the South.”

38. Richmond Committee of Safety Resolutions, Niles Weekly Register, August 22, 1835, 445.

39. Niles Weekly Register, August 22, 1835, 441.

40. Washington Globe, August 15, 1835.

41. Yet another example can be found in the Arkansas Advocate, "Some of Garrison's disciples declare themselves ready to suffer martyrdom even, in the good cause. If they will travel this way they can be accommodated." Reprinted in Niles Weekly Register, October 3, 1835, 74.

42. Andrew Jackson to Amos Kendall, August 9, 1835, in Correspondence of Andrew Jackson, vol 5, ed. John Spencer Bassett (Washington, 1931), 360-61.

43. For example, future president "His Accidency" John Tyler was mortified to have been a recipient of the newspapers. According to his biographer Oliver Perry Chitwood, Tyler "addressed one of these [Virginia anti-abolition] meetings held in James City County and another at Gloucester Courthouse.” At the August 22, 1835, meeting in Gloucester, Tyler argued that the newspapers had "invaded our firesides, and under our own roofs is sharpening the dagger for midnight assassination, and exciting cruelty and bloodshed. The postoffice department, which was established for the purpose of commercial interchange or to transport from remote places the friendly greeting of those of kindred blood, has been converted into a vehicle for distributing incendiary pamphlets, with which our land is at this moment deluged." Oliver Perry Chitwood, John Tyler: Champion of the Old South (Newtown, CT: American Political Biography Press, 1939), 142-143.

44. Speech of President Andrew Jackson, The Congressional Globe, Senate, 24th Congress, 1st Session, December 8, 1835, 10. 
45. Jackson, The Congressional Globe, 10.

46. Jackson, The Congressional Globe, 10.

47. Eaton, "Censorship of the Southern Mails," 273.

48. The lens of war rhetoric gives meaning to the abolitionist mail crisis because its participants viewed themselves as engaged in warfare over abolition, even if we would not now call their experience "warfare" proper. Indeed, slaveholders often described the crisis with war metaphors. For example, according to southerner Samuel Jenks Smith in Niles Weekly Register, "But you will find, when we are satisfied that the incendiaries are only to be put down by the hand of violence, that we have not forgotten the spirit of our fathers, which led them to destroy the Gaspee, and throw the tea of Englishmen into the ocean, even though the act was not sanctioned by the law of the land." Samuel Jenks Smith, Niles Weekly Register, October 3, 1835. The Gaspee was a British war ship destroyed by Rhode Islanders on June 10, 1772. The American Anti-Slavery Society explicitly refuted the charge that it meant to provoke insurrection in its September 3, 1835, Address to the Public: "We are charged with sending incendiary publications to the South. If by the term incendiary is meant publications containing arguments and facts to prove Slavery to be a moral and political evil, and that duty and policy require its immediate abolition, the charge is true. But if this term is used to imply publications encouraging insurrection, and designed to excite the Slaves to break their fetters, the charge is utterly and unequivocally false. We beg our fellow-citizens to notice, that this charge is made without proof, and by many who confess that they have never read our publications, and that those who made it offer to the public no evidence from our writings in support of it.” Arthur Tappen, John Rankin, William Jay, Elizur Wright, and Abraham Cox (The American Anti-Slavery Society 143 Nassau Street, New York, September 3, 1835).

49. See Robert L. Ivie, "Images of Savagery in American Justifications for War," Communication Monographs 47 (1980): 279-291; Robert L. Ivie, "Presidential Motives for War," Quarterly Journal of Speech 60 (1974): 337-345; Robert L. Ivie, “The Ideology of Freedom's 'Fragility' in American Foreign Policy Argument," Journal of the American Forensic Association 24 (1987): 27-36; Robert L. Ivie, “The Metaphor of Force in Prowar Discourse: The Case of 1812," Quarterly Journal of Speech 68 (1982): 240-253. His most extensive discussion of the subject is: Robert L. Ivie, Democracy and America's War on Terror (Tuscaloosa: University of Alabama Press, 2005); Ronald H. Carpenter, “America's Tragic Metaphor: Our Twentieth-Century Combatants as Frontiersmen," Quarterly Journal of Speech 9 (1990): 1-22; Ronald F. Reid, "New England Rhetoric and the French War, 1754-1760: A Case Study in the Rhetoric of War," Communication Monographs 43 (1976): 259-286; James L. Golden, "Hilliard vs. Yancey: Prelude to the Civil War," Quarterly Journal of Speech 42 (1956): 35-44; Craig R. Smith, "The Anti-War Rhetoric of Daniel Webster," Quarterly Journal of Speech 85 (1999): 1-16; David Zarefsky, "President Johnson's War on Poverty: The Rhetoric of Three 'Establishment' Movements," Communication Monographs 44 (1977): 353-373; Everett Hunt, “The Rhetorical Mood of World War II," Quarterly Journal of Speech 29 (1943): 1-5; G. Thomas Goodnight, "Ronald Reagan's Re-formulation of the Rhetoric of War: Analysis of the 'Zero Option,' 'Evil Empire,' and 'Star Wars' Addresses," Quarterly Journal of Speech 72 (1986): 390-414; Lyman Bryson, "The Rhetoric of Conciliation," Quarterly Journal of Speech 39 (1953): 437-443; James W. Hikins, "The Rhetoric of 'Unconditional Surrender' and the Decision to Drop the Atomic Bomb," Quarterly Journal of Speech 69 (1983): 379-400; Bryan C. Taylor and Stephen J. Hartnett, "National Security, and All That It Implies ... ' Communication and (Post-) Cold War Culture," Quarterly Journal of Speech 86 (2000): 465-491. 
50. Ivie, “Images of Savagery," 281.

51. Charleston Southern Patriot quoted in Niles Weekly Register, October 3, 1835, 73.

52. According to Freeman, "It would be hard to overstate the importance of personal honor to an eighteenth-century gentleman, let alone to a besieged leader whose status was under attack. Honor was the core of a man's identity, his sense of self, his manhood. A man without honor was no man at all. Honor was also entirely other-directed, determined before the eyes of the world; it did not exist unless bestowed by others. Indeed, a man of honor was defined by the respect that he received in public.” Joanne B. Freeman, Affairs of Honor: National Politics in the New Republic (New Haven: Yale University Press, 2001), xvi.

53. See, for example, John G. Peristiany and Julian Pitt-Rivers, eds, Honor and Grace in Anthropology (Cambridge: Cambridge University Press, 2005).

54. Bertram Wyatt-Brown, Honor and Violence in the Old South (New York: Oxford University Press, 1986), vii.

55. Wyatt-Brown, Honor and Violence in the Old South, 27.

56. It is difficult to accurately calculate the frequency of duels in the South, but anecdotal evidence provided by Bertram Wyatt-Brown and Joanne B. Freeman suggests that they occurred often. See also Jack R. Williams, Dueling in the Old South: Vignettes of Social History (College Station: Texas A\&M University Press, 1980).

57. All quotes in this paragraph found in Wyatt-Brown, Honor and Violence in the Old South, vii-viii. See also his larger volume, Bertram Wyatt-Brown, Southern Honor: Ethics and Behavior in the Old South (New York: Oxford University Press, 1982), and his more recent, Bertram Wyatt-Brown, The Shaping of Southern Culture: Honor, Grace, and War, 1760s1880s (Chapel Hill: University of North Carolina Press, 2001).

58. Wyatt-Brown, Honor and Violence in the Old South, 14.

59. Celeste Michelle Condit, "The Functions of Epideictic: The Boston Massacre Orations as Exemplar," Communication Quarterly 33 (1985): 284-299, 289; Bonnie J. Dow, "The Function of Epideictic and Deliberative Strategies in Presidential Crisis Rhetoric," Western Journal of Speech Communication 53 (1989): 294-310; John M. Murphy, “Our Mission and Our Moment': George W. Bush and September 11th,” Rhetoric \& Public Affairs 6 (2003): 607-632; Denise M. Bostdorff, "George W. Bush's Post-September 11 Rhetoric of Covenant Renewal: Upholding the Faith of the Greatest Generation," Quarterly Journal of Speech 89 (2003): 292-319; Lester C. Olson, "Benjamin Franklin's Commemorative Medal Libertas Americana: A Study in Rhetorical Iconology," Quarterly Journal of Speech 76 (1990): 23-45; Ned O'Gorman, “Aristotle's Phantasia in the Rhetoric: Lexis, Appearance, and the Epideictic Function of Discourse," Philosophy and Rhetoric 38 (2005): 16-40; Vanessa B. Beasley, “The Rhetoric of Ideological Consensus in the United States: American Principles and American Pose in Presidential Inaugurals," Communication Monographs 68 (2001): 169-183. 